Ekuitas: Jurnal Pendidikan Ekonomi

Volume 9, Number 1, Tahun 2021, pp. 85-92

P-ISSN : 2354-6107 E-ISSN : 2549-2292

DOI : $10.23887 /$ ekuitas.v9i1.27363

Open Access: https://ejournal.undiksha.ac.id/index.php/EKU

\title{
Analisis Tingkat Literasi Keuangan SMK N 1 Singaraja dan SMA N 4 Singaraja
}

\section{El Dimas Handy Irhamy ${ }^{1}$, Wayan Cipta²}

1,2Universitas Pendidikan Ganesha, Singaraja - Indonesia

\section{A R T I C L E I N F O}

Article history:

Received July, 222020

Received in revised form June, 172021

Accepted June, 182021

Available online June, 28 2021

Kata Kunci:

Literasi keuangan,

perbandingan, sekolah,

siswa.

Keywords:

Comparison, financial

literacy, school, student.

\begin{abstract}
A B S T R A K
Penelitian ini bertujuan untuk mengetahui perbandingan tingkat literasi keuangan dari SMK N 1 singaraja dan SMA N 4 Singaraja. Penelitian ini merupakan jenis penelitian kuantitatif dengan pendekatan deskriptif komparatif. Subjek dalam penelitian ini adalah siswa SMK N 1 Singaraja dan SMA N 4 singaraja dan Objek dalam penelitian ini adalah tingkat literasi keuangan siswa. sampel dalam penelitian ini sebanyak 97 dengan menggunakkan rumus Slovin. Data yang digunakan adalah data primer dengan menggunakan kuesioner. Kuesioner terdiri dari dua bagian yaitu data diri dan pertanyaan terkait literasi keuangan. Kuesioner dianalisis dengan teknik analisis deskriptif komparatif. Rata-rata tingkat literasi keuangan keseluruhan adalah $71,15 \%$ dalam kategori sedang. Tingkat literasi keuanan SMK N 1 singaraja sebesar 72,8\% termasuk dalam kategori sedang dan SMA N 4 Singaraja sebesar 69\% termasuk dalam kategori sedang. Perbedaan tingkat literasi keuangan tidak terlalu signifikan karena tingkat literasi tidak berbeda terlalu jauh dan msih pada kategori yang sama
\end{abstract}

\section{A B S T R A C T}

This study aims to determine the comparison of the level of financial literacy of SMK N 1 Singaraja and SMA N 4 Singaraja. This research is a type of quantitative research with a comparative descriptive approach. The subjects in this study were students of SMK N 1 Singaraja and SMA N 4 singaraja and the object in this study was the level of student financial literacy. The sample in this study were 97 by using Slovin formula. The data used are primary data using a questionnaire. The questionnaire consisted of two parts, namely personal data and questions related to financial literacy. The questionnaire was analyzed with comparative descriptive analysis techniques. The average overall financial literacy rate is $71.15 \%$ in the medium category. The level of financial literacy of SMK N 1 Singaraja is $72.8 \%$ included in the medium category and SMA N 4 Singaraja by $69 \%$ is included in the medium category. The difference in the level of financial literacy is not too significant because the level of literacy does not differ too much and still in the same category

\footnotetext{
* Corresponding author.

E-mail : edimashandyirhamy@gmail.com (El Dimas Handy Irhamy)
} 


\section{Pendahuluan}

Financial/ keuangan sebuah cabang ilmu yang mempelajari bagaimana cara mengetahui berbisnis individu, meningkatkan organisasi, mengalokasi, menggunakan sumber daya moneter dengan sejalannya waktu, dan juga menghitung risiko dalam menjalankan proyeknya (Wikipedia). Dalam pengelolaan keuangan pribadi dibutuhkan kecerdasan keuangan. Kecerdasan keuangan merupakan sebuah komponen dalam human capital. Individu harus memiliki pengetahuan dan sebuah keterampilan untuk mengelola sumber keuangan pribadinya secara efektif sehingga mampu mencapai kesejahteraan. Pengelolaan keuangan tidak lepas dari literasi keuangan, Menurut Otoritas Jasa Keuangan (OJK) literasi keuangan adalah rangkaian proses atau aktivitas untuk meningkatkan pengetahuan, keyakinan serta keterampilan konsumen dan masyarakat luas sehingga mereka mampu mengelola keuangan dengan baik, atau secara singkat dapat dikatakan sebagai pengetahuan dan kemampuan pengelolaan keuangan. Literasi tidak hanya terbatas pada pengertian dan pengetahuan, keterampilan dan juga keyakinan terhadap lembaga keuangan, namun sikap dan perilaku dapat mempengaruhi peningkatan literasi keuangan dan kesejahteraan masyarakat. Indonesia sebagai negara berkembang yang memiliki wilayah yang sangat luas dan memiliki pendudukan yang sangat besar dan masuk kedalam urutan nomor 4 dunia, Indonesia sedang mengalami masalah-masalah keuangan. Sebagian besar penduduk Indonesia belum memahami masalah keuangan. Dengan kata lain Indonesia berada dalam krisis keuangan, atau pada saat ini disebut dengan memiliki tingkat literasi yang rendah yang dimana hal tersebut dikemukan oleh OJK pada tahun 2013, 2016 dan 2019. Pada tahun 2013 tingkat literasi keuangan Indonesia hanya mencapai 21,8\% memang mendapatkan peningkatan selama kurun waktu 3 tahun, pada tahun 2016 tingkat literasi keuangan Indonesia meningkat mencapai angka 29,9\%, dan kembali mengalami peningkatan pada tahun 2019 menjadi 38,03\%, namun tetap saja hasil tersebut masih dalam kategori literasi yang rendah.

Literasi keuangan memiliki manfaat yang menurut Jappellin (2010) dapat terbagi menjadi 3 kelompok yaitu: (1) sisi aset, literasi yang tinggi akan dapat membantu melihat risiko dari sebuah portofolio, alokasi portofolio dapat dilakukan dengan efisien, dan tingginya jumlah tabungan, (2) sisi hutang, seseorang akan berfikir untuk memiliki hutang hipotik dan juga memiliki kartu kredit karena dapat memberikan risiko keuangan, dan (3) sisi makro, literasi keuangan akan memberikan kontribusi terhadap pasar dan kebijakan. Sedangkan dampak dari rendahnya tingkat literasi menurut Martha selaku Kepala Departemen Literasi dan Inklusi Keuangan OJK bahwa Literasi yang rendah dapat menyebabkan empat hal yaitu: (1) tidak memiliki tujuan keuangan. Seseorang yang memiliki literasi rendah tidak akan memiliki tujuan keuangan karena akan menggunakan uang yang didapat tidak secara bijak, (2) tidak memiliki perencanaan keuangan yang baik. Seseorang yang tidak memiliki tujuan pastinya akan cendrung tidak memiliki perencanaan keuangan yang baik agar dapat mencapai tujuan yang diinginkan, (3) penempatan investasi yang tidak tepat. Literasi yang rendah akan berdampak pada pemilihan instrument investasi yang tidak tepat, dan (4) terjebak oleh praktik investasi bodong.

Krisis keuangan dan berbagai masalah yang berkaitan dengan ketidakmampuan mengelola keuangan semakin menyadarkan betapa pentingnya literasi keuangan. literasi keuangan sangatlah berkaitan dengan kesejahteraan seorang individu dalam perekonomian baik sekarang dan masa yang akan datang. Pengetahuan terkait tentang keterampilan keuangan akan sangat berpengaruh pada pengelolaan keuangan, baik dalam jangka pendek maupun jangka panjang. Masalah keuangan yang terjadi tidak hanya terletak pada fungsi pendapatan (pendapatan rendah) namun masalah keuangan dapat terjadi jika tidak terdapat adanya perencanaan keuangan yang tepat. Keterbatasan financial dan juga tingkat literasi akan dapat menyebabkan kesalahan-kesalahan financial yang fundamental seperti kesalahan dalam mengelola pendapatan dan pengelolaan kredit yang diterima. Keterbatasan tersebut juga dirasakan oleh siswa dan siswi. Keterbatasan tersebut adalah keterbatasan pendapatan yang hanya berupa uang saku yang diberikan oleh orang tua kepada anak (siswa dan siswi) namun kebutuhan yang semakin meningkat. Sehingga siswa/i harus tau prioritas yang harus didahulukan. Menurut 0JK dalam bisnis.com pada tahun 2015 tingkat literasi keuangan pelajar di Indonesia baru 28\%. Dari rendahnya tingkat literasi keuangan masyarakat terlebih pelajar, OJK membuat kebijakan untuk mengembangkan literasi keuangan. Salah satu kebijakan yang dikeluarkan OJK adalah memasukkan kurikulum terkait pengembangan literasi keuangan ke sekolah bahkan dari Sekolah Dasar (SD)/ sederajat hingga Sekolah Menegah Atas (SMA)/ sederajat.

Siswa/i adalah generasi penerus tongkat estafet untuk pengurusan pemerintahan negara ini dan merupakan aset yang sangat berharga bagi negara. Sebagai seorang siswa kewajiban yang harus dipenuhi bukanlah semata-mata hanya belajar saja, namun juga harus mengasah softskill atau bakat yang dimiliki untuk menghadapi perkembangan zaman yang semakin pesat. Di zaman yang sudah berkembang pesat ini kebutuhan manusia semakin meningkat terlebih bagi siswa, siswa harus sangat memperhatikan pengelolaan keuangannya secara tepat agar dapat memenuhi seluruh kebutuhan. Apalagi seorang siswa 
hanya mendapatkan jatah uang saku yang terbatas. Disinilah tantangan dari seorang siswa untuk mengatasi keadaan keuangannya agar dapat memenuhi seluruh kebutuhannya. Softskill yang harus dimiliki adalah literasi keuangan sebagai perencanaan jangka panjang dan jangka pendek. pengelolaan keuangan jangka pendek akan mampu membantu untuk mengendalikan keinginan dalam mengkonsumsi produk yang dirasa kurang memiliki kepentingan, sedangkan untuk pengelolaan jangka panjang dapat membantu perencanaan masa depan seperti menabung untuk masuk dalam perguruan tinggi ternama dan terfavorit.

Sekolah adalah tempat edukasi kedua para siswa dan siswi selain dirumah. Sekolah merupakan lembaga formal yang bisa mejadi tempat edukasi literasi keuangan sejak dini. Edukasi literasi keuangan adalah salah satu cara agar literasi keuangan siswa/i menjadi baik. Jika tidak ada edukasi tentang literasi keuangan, maka akan berdampak pada timbulnya masalah keuangan akibat kesalahan dalam mengambil keputusan terkait pengeluaran yang dilakukan. Hal tersebut sejalan dengan Hidajat (2015) mengatakan bahwa literasi keuangan yang rendah merupakan persoalan serius karena bisa memberi dampak negatif pada perilaku keuangan. Pemilihan tersebut didasarkan pada kebijakan OJK yang melakukan pengembangan literasi Keuangan di SD hingga SMA. SMA/ Sederajat memiliki 2 pilihan antara berkerja dan melanjutkan belajar di perguruan tinggi, sehingga diperlukan pengetahuan keuangan untuk pengelolaan ataupun perencanaan keuangan yang baik. Selain Hal tersebut, pada materi pembelajaran yang diterima, seperti halnya yang diketahui bahwa SMA dalam sekolah yang tidak terprogram secara mengkhusus dan tidak ada penerjunan ke lapangan, berbeda dengan SMK yang memang diprogram dengan secara khusus dan terjun langsung ke lapangan kerja dalam bentuk praktek kerja lapangan. Terlebih lagi subjek yang Peneliti pilih adalah SMK N 1 Singaraja adalah sekolah ekonomi bisnis yang dimana diajarkan ekonomi secara khusus, sedangkan untuk SMA peneliti memilih menggunakan SMA N 4 Singaraja adalah sekolah menegah atas umum dimana materi pembelajaran masalah ekonomi diberikan secara umum.

Berdasarkan latar belakang penelitian yang telah dipaparkan, maka rumusan masalah dalam penelitian ini adalah: (1) Bagaimanakah tingkat literasi keuangan siswa/i SMK N 1 Singaraja? (2) Bagaimanakah tingkat literasi keuangan siswa/i SMA N 4 Singaraja? (3) Bagaimanakah perbandingan tingkat literasi keuangan siswa/i SMK N 1 Singaraja dan SMA N 4 Singaraja?.

Tujuan dari penelitian ini adalah untuk mengetahui hal-hal sebagai berikut: (1) Tingkat literasi keuangan pada siswa/i SMK N 1 Singaraja (2) Tingkat literasi keuangan pada siswa/i SMA N 4 Singaraja (3) Perbedaan tingkat literasi keuangan siswa/i SMK N 1 Singaraja dan SMA N 4 Singaraja.

\section{Metode}

Penelitian ini dilaksanakan di SMK N 1 Singaraja dan SMA N 4 Singaraja dengan melakukan penyebaran kuesioner pada siswa dan siswi. Rentan waktu penelitian yang disusun untuk memudahkan dalam pelaksanaan kegiatan penelitian ini adalah 9 bulan. Penelitian ini dilakukan sejak bulan November sampai dengan bulan Juli.

Penelitian ini menggunakan metode penelitian Deskriptif komparatif. Menurut Anshori dan Iswati (2009) penelitian komparatif adalah penelitian yang membandingkan antara satu variabel dengan variabel lain, atau variabel yang sama dengan membandingkan dua sampel atau lebih, atau dibandingkan dalam waktu yang berbeda. Dalam penelitian ini, peneliti akan melakukan penelitian dengan variabel yang sama dengan membandingkan dua sampel berbeda yang membandingkan tingkat literasi keuangan dari SMK N 1 Singaraja dengan SMA N 4 Singaraja.

Menurut Sugiyono (2013), populasi adalah wilayah generalisasi yang terdiri atas objek atau subjek yang mempunyai kualitas atau karakteristik tertentu yang ditetapkan oleh peneliti untuk dipelajari dan kemudian ditarik kesimpulannya. Populasi dari penelitian ini adalah Siswa SMK N 1 Singaraja sejumlah 1214 siswa dan SMA N 4 Singaraja sejumlah 1594 dengan total 2808 siswa dengan rincian jumlah siswa kelas X sebanyak 913, kelas XI sebanyak 927 dan kelas XII sebanyak 968.

Populasi yang sangat besar maka dilakukan perhitungan jumlah sampel. Menurut Sugiyono (2011) Sampel adalah bagian dari jumlah dan karakteristik yang dimiliki oleh populasi tersebut. Perhitunan tersebut dilakukan dengan menggunakan rumus slovin sebagai berikut.

$$
n=\frac{\mathrm{N}}{1+\mathrm{N} \mathrm{e}^{2}}
$$

Keterangan:

$\mathrm{n} \quad=$ Jumlah sampel

$\mathrm{N} \quad=$ Jumlah Populasi

$\mathrm{E} \quad=$ Batas Toleransi kesalahan (error tolerance) 
Berdasarkan rumus tersebut jumlah sampel yang digunakan dalam penelitian ini adalah sebanyak 97 responden.

Teknik pengambilan sampel pada penelitian ini menggunakan teknik proportional stratified random sampling karena populasi dalam penelitian ini tidak homogen dan berstrata proporsional. Alokasi sampel untuk masing-masing sekolah pada tabel 1 berikut.

Tabel 1. Alokasi Sampel

\begin{tabular}{ccc}
\hline Sekolah & Proportional & Jumlah \\
\hline SMK N 1 Singaraja & $1594 / 2808 \times 97=55,06$ & 55 \\
SMA N 4 Singaraja & $1214 / 2808 \times 97=41.93$ & 42 \\
\hline & Total & 97 \\
\hline
\end{tabular}

Sumber : data primer yang telah diolah, 2020

Penelitian ini akan menggunakan data primer yang akan didapatkan dengan cara menyebar kuesioner pada sampel penelitian. Menurut Sugiyono (2013) kuesioner adalah teknik pengumpulan data yang dilakukan dengan cara memberikan seperangkat pertanyaan atau pernyataan tertulis kepada responden untuk dijawab. Bagian pertama, kuesioner berisikan data responden seperti nama, kelas, jurusan dan jenis kelamin, dan bagian kedua, kuesioner berisikan pertanyaan yang berkaitan dengan literasi keuangan terkait dengan tujuan penelitian untuk mengetahui tingkat literasi keuangan siswa.

Pengujian instrumen penelitian yang dilakukan pada penelitian ini adalah uji validitas dan reliabilitas instrumen. Pengujian validitas instrumen dilakukan untuk memastikan bahwa instrumen yang digunakan dalam penelitian mencakup terhadap apa yang hendak diukur.

Tabel 2. Hasil Uji Validitas Kuesioner

\begin{tabular}{cccc}
\hline $\begin{array}{c}\text { No Butir } \\
\text { Soal }\end{array}$ & r hitung & $\begin{array}{c}\text { r-tabel }(\mathrm{N}=30, \\
\alpha=5 \%)\end{array}$ & Keterangan \\
\hline 1 & 0,421 & 0,361 & Valid \\
2 & 0.421 & 0,361 & Valid \\
3 & 0.440 & 0,361 & Valid \\
4 & 0,394 & 0,361 & Valid \\
5 & 0,496 & 0,361 & Valid \\
6 & 0,554 & 0,361 & Valid \\
7 & 0,364 & 0,361 & Valid \\
8 & 0,537 & 0,361 & Valid \\
9 & 0,548 & 0,361 & Valid \\
10 & 0,462 & 0,361 & Valid \\
11 & 0,596 & 0,361 & Valid \\
12 & 0,460 & 0,361 & Valid \\
13 & 0,416 & 0,361 & Valid \\
14 & 0,393 & 0,361 & Valid \\
15 & 0,388 & 0,361 & Valid \\
16 & 0,551 & 0,361 & Valid \\
17 & 0,496 & 0,361 & Valid \\
18 & 0,647 & 0,361 & Valid \\
19 & 0,393 & 0,361 & Valid \\
20 & 0,495 & 0,361 & Valid \\
21 & 0,399 & 0,361 & Valid \\
22 & 0,449 & 0,361 & Valid \\
23 & 0,463 & 0,361 & Valid \\
24 & 0,467 & 0,361 & Valid \\
25 & 0,408 & 0,361 & Valid \\
\hline
\end{tabular}

Sumber : Data primer yang telah diolah, 2020

Hasil pengujian instrumen penelitian (kuesioner) menunjukkan bahwa dari 25 butir soal yang diuji seluruhnya dinyatakan valid, sedangkan penelitian ini hanya akan menggunakan 20 butir pernyataan, maka akan dihapus lima pernyataan dengan cara menghapus satu pertanyaan di setiap indikator variabel penelitian. 
pengujian reliabilitas digunakan untuk mengungkapkan kestabilan instrumen dari waktu ke waktu. Umar (2013) menyatakan bahwa uji reliabilitas berguna untuk menetapkan apakah instrumen yang digunakan, yaitu kuesioner dapat digunakan lebih dari satu kali paling tidak oleh responden yang sama.

Tabel 3. Hasil Uji Reliabilitas Kuesioner

\begin{tabular}{rrr}
\hline Cronbach's Alpha & N of Items & \\
\hline, 854 & & 25 \\
\hline
\end{tabular}

Sumber : Data primer yang telah diolah 2020

Tabel diatas, menunjukan nilai cronbach's alpha pada uji instrumen penelitian yang dilakukan pada 30 orang siswa. Uji instrumen yang dilakukan mendapatkan hasil 0,854 yang lebih besar dari 0,600 maka butir kuesioner yang digunakan untuk mengukur tingkat literasi dapat dikatakan reliabel.

Sumber : data primer yang telah diolah, 2020

Teknis analisis data yang akan digunakan adalah analisis statistik deskriptif. Menurut Sugiyono (2013: 206), statistik deskriptif adalah statistik yang digunakan untuk menganalis data dengan cara mendeskripsikan atau menggambarkan data yang terkumpul sebagaimana adanya tanpa maksud membuat kesimpulan yang berlaku untuk umum atau generalisasi.

Tingkat literasi keuangan data didapatkan dari jawaban responden dengan menggunakan kuesioner, dalam kuesioner tersebut terdapat 20 pertanyaan yang dibuat dengan menggunakkan aspekaspek yang dikemukakan oleh Chen and Volpe (1998), setiap pertanyaan yang berhasil dijawab dengan benar akan mendapatkan nilai 1 dan jika jawaban salah tidak akan mendapatkan nilai atau nol, kemudian jawaban benar dibagi jumlah soal lalu dikali 100 persen untuk melihat nilai atau tingkat literasi keuangan siswa. Hasil dari perhitungan tingkat literasi siswa tersebut akan dibandingkan dengan kriteria tingkat literasi keuangan menurut Chen dan Volpe (1998), dengan kategori yaitu: (1) Tinggi, jika tingkat literasi melebihi 80\%, (2) Menengah, jika tingkat literasi antara 60\% sampai dengan 80\%, (3) Rendah, jika tingkat literasi kurang dari 60\%.

Hasil tingkat literasi keuangan tersebut akan dibandingkan antara SMK N 1 Singaraja dengan SMA N 4 Singaraja dengan menggunakan hasil perhitungan statistik dan persentase pada setiap indikator variabel.

\section{Hasil dan pembahasan} tabel 4 .

Hasil analisis statistik deskriptif tingkat literasi keuangan secara keseluruhan dapat dilihat pada

Tabel 4. Tingkat Literasi Keuangan Keseluruhan

\begin{tabular}{cc}
\hline Keterangan & Literasi Keuangan \\
\hline Nilai Rata-Rata & $71.15 \%$ \\
Nilai Minimal & $45 \%$ \\
Nilai Maksimal & $95 \%$ \\
\hline
\end{tabular}

Sumber: data primer yang telah diolah, 2020

Berdasarkan analisis stasistik deskriptif menunjukkan bahwa secara keseluruhan literasi keuangan siswa (SMK N 1 Singaraja dan SMA N 4 Singaraja) berada pada kategori sedang (60\%-80\%) yaitu sebesar $71,15 \%$ dari nilai rata-rata keseluruhan jawaban responden, sedangkan literasi keuangan siswa berdasarkan kategori dari 97 siswa yang menjadi responden, terdapat 11 orang dalam kategori rendah, terdapat 17 siswa dalam kategori tinggi dan mayoritas responden dalam penelitian ini berada pada kategori sedang yaitu sebanyak 69 siswa. Hal ini berarti sebagaian besar siswa sudah memiliki pengetahuan dan pemahaman yang cukup baik mengenai dasar-dasar keuangan baik pengetahuan umum keuangan, simpanan, pinjaman, asuransi dan investasi. Nilai maksimal yang diperoleh oleh responden adalah 95\% dan nilai minimal yang diperoleh responden adalah 45\%. Hal ini berarti dari 20 pertanyaan yang diberikan terdapat siswa yang dapat menjawab benar 19 pertanyaan dan terdapat siswa yang hanya dapat menjawab benar 9 pertanyaan

Hasil analisis statistik deskriptif tingkat literasi keuangan SMK N 1 Singaraja Dan SMA N 4 Singaraja dapat dilihat pada tabel 5 . 
Tabel 5. Tingkat Literasi Keuangan SMK N 1 Singaraja dan SMA N 4 Singaraja

\begin{tabular}{ccc}
\hline Keterangan & SMK N 1 Singaraja & SMA N 4 Singaraja \\
\hline Rata-Rata & $75.8 \%$ & $66.5 \%$ \\
Nilai Minimal & $50 \%$ & $45 \%$ \\
Nilai Maksimal & $95 \%$ & $90 \%$ \\
\hline
\end{tabular}

Sumber: data primer yang telah diolah, 2020

Berdasarkan analisis statistik deskriptif menunjukkan bahwa literasi keuangan siswa SMK N 1 Singaraja berada pada kategori sedang (60\%-80\%) yaitu 75,8\% dari nilai rata-rata responden, sedangkan literasi keuangan siswa berdasarkan kategori dari 55 siswa yang menjadi responden, terdapat 2 orang dalam kategori rendah, terdapat 13 siswa dalam kategori tinggi dan mayoritas responden dalam penelitian ini berada pada kategori sedang yaitu sebanyak 40 siswa. Hal ini berarti sebagaian besar siswa sudah memiliki pengetahuan dan pemahaman yang cukup baik mengenai dasar-dasar keuangan baik pengetahuan umum keuangan, simpanan, pinjaman, asuransi dan investasi. Nilai maksimal yang diperoleh oleh responden adalah 95\% dan nilai minimal yang diperoleh responden adalah 50\%. Hal ini berarti dari 20 pertanyaan yang diberikan terdapat siswa yang dapat menjawab benar 19 pertanyaan dan terdapat siswa yang hanya dapat menjawab benar 10 pertanyaan. Sedangkan berdasarkan analisis statistik deskriptif menunjukkan bahwa literasi keuangan siswa SMA N 4 Singaraja berada pada kategori sedang $(60 \%-80 \%)$ yaitu $66,5 \%$ dari nilai rata-rata responden, sedangkan literasi keuangan siswa berdasarkan kategori dari 42 siswa yang menjadi responden, terdapat 9 orang dalam kategori rendah, terdapat 14 siswa dalam kategori tinggi dan mayoritas responden dalam penelitian ini berada pada kategori sedang yaitu sebanyak 29 siswa. Hal ini berarti sebagaian besar siswa sudah memiliki pengetahuan dan pemahaman yang cukup baik mengenai dasar-dasar keuangan baik pengetahuan umum keuangan, simpanan, pinjaman, asuransi dan investasi. Nilai maksimal yang diperoleh oleh responden adalah $90 \%$ dan nilai minimal yang diperoleh responden adalah $45 \%$. Hal ini berarti dari 20 pertanyaan yang diberikan terdapat siswa yang dapat menjawab benar 18 pertanyaan dan terdapat siswa yang hanya dapat menjawab benar 9 pertanyaan.

Berdasarkan analisis statistik deskriptif tingkat literasi keuangan SMK N 1 Singaraja lebih tinggi dibandingkan dengan SMA N 4 Singaraja, dapat dilihat pada Tabel diatas, dapat diketahui bahwa nilai rata-rata, nilai maksimal serta nilai minimal siswa SMK N 1 Singaraja lebih mengungguli SMA N 4 Singaraja. Perbandingan tersebut tidak terlalu signifikan karena nilai rata-rata SMK N 1 singaraja dan SMA N 4 Singaraja masih pada kategori yang sama yaitu pada kategori sedang.

Hasil analisis tingkat literasi keuangan menggunakan kategori Chen dan Volpe (1998) dapat dilihat pada tabel 6 .

Tabel 6. Tingkat Literasi Keuangan kategori Chen dan Volpe

\begin{tabular}{cccc}
\hline NO & Tingkat Literasi Keuangan & $\begin{array}{c}\text { SMK N 1 Singaraja } \\
\text { (Jumlah siswa) }\end{array}$ & $\begin{array}{c}\text { SMA N 4 Singaraja } \\
\text { (Jumlah siswa) }\end{array}$ \\
\hline 1 & Rendah $(<60 \%)$ & 2 & 9 \\
2 & Sedang $(60 \%-80 \%)$ & 40 & 29 \\
3 & Tinggi $(>80 \%)$ & 13 & 4 \\
\hline & Total & 55 & 42 \\
\hline
\end{tabular}

Sumber: data primer yang telah diolah, 2020

Berdasarkan data diatas, dapat diketahui bahwa bahwa dari 55 responden siswa SMK N 1 Singaraja terdapat 2 siswa yang berada pada kategori tingkat literasi keuangan rendah, 40 siswa yang berada pada kategori tingkat literasi keuangan sedang, dan 13 siswa yang berada pada kategori tingkat literasi tinggi. Sedangkan Berdasarkan data diatas, dapat diketahui bahwa bahwa dari 42 responden siswa SMA N 4 Singaraja terdapat 9 siswa yang berada pada kategori tingkat literasi keuangan rendah, 29 siswa yang berada pada kategori tingkat literasi keuangan sedang, dan 4 siswa yang berada pada kategori tingkat literasi keuangan tinggi.

Berdasarkan analisis tingkat literasi keuangan siswa menurut kategori tingkat literasi SMK N 1 Singaraja lebih tinggi dibandingkan dengan SMA N 4 Singaraja, dapat dilihat pada Tabel diatas, dapat diketahui bahwa persentase tingkat literasi keuangan siswa pada setiap kategori SMA N 4 Singaraja jauh lebih tinggi dibangdinkan dengan SMK N 1 Singaraja. Perbandingan tersebut tidak terlalu singnifikan karena mayoritas tingkat literasi keuangan siswa di kedua sekolah masih pada kategori yang sama yaitu pada kategori sedang. 
Hasil analisis persentase responden menjawab benar dapat dilihat pada tabel 7.

Tabel 7. Persentase jawaban benar responden per indikator variabel

\begin{tabular}{ccc}
\hline Aspek & SMK N 1 Singaraja & SMA N 4 Singaraja \\
& $(\%)$ & $(\%)$ \\
\hline Pengetahuan Umum & 78.9 & 70,7 \\
Keuangan & 84 & 73 \\
Simpanan & 62 & 47,6 \\
Pinjaman & 69,7 & 57,1 \\
Asuransi & 79,1 & 74,3 \\
Investasi & &
\end{tabular}

Sumber: data primer yang telah diolah, 2020

Dari data diatas dapat diketahui tentang tingkat literasi keuangan SMK N 1 Singaraja yang dilihat dari rata-rata jawaban benar per aspek penelitian. Nilai rata-rata dari aspek pengetahuan umum keuangan adalah sebesar 78,9\%. Nilai rata-rata dari aspek simpanan adalah sebesar $84 \%$. Nilai rata-rata dari aspek pinjaman adalah sebesar $62 \%$. Nilai rata-rata dari aspek asuransi adalah sebesar $69,7 \%$. Nilai rata-rata dari aspek investasi adalah sebesar 79,1\%. Sedangkan Dari data diatas dapat diketahui tentang tingkat literasi keuangan SMA N 4 Singaraja yang dilihat dari rata-rata jawaban benar per aspek penelitian. Nilai rata-rata dari aspek pengetahuan umum keuangan adalah sebesar 70,7\%. Nilai rata-rata dari aspek simpanan adalah sebesar 73\%. Nilai rata-rata dari aspek pinjaman adalah sebesar $47,6 \%$. Nilai rata-rata dari aspek asuransi adalah sebesar $57,1 \%$. Nilai rata-rata dari aspek investasi adalah sebesar $74,3 \%$.

Berdasarkan analisis dari persentase jawaban benar per indikator variabel SMK N 1 Singaraja lebih tinggi dibandingkan dengan SMA N 4 Singaraja. Dapat dilihat pada tabel diatas, dapat diketahui bahwa persentase jawaban benar pada setiap indikator SMK N 1 Singaraja lebih Tinggi dibandingkan dengan SMA N 4 Singaraja. Perbadingan persentase tersebut tidak terlalu signifikan pada indikator pengetahuan umum keuangan dan investasi karena masih dalam satu kategori yang sama, sedangkan simpanan, pinjaman dan asuransi perbandingan tersebut sigfinikan karena persentase berada pada ketegori yang yang berbeda.

\section{Simpulan dan saran}

Berdasarkan hasil analisis data yang telah dilakukan dalam penelitian ini, maka simpulan yang diperoleh dari pembahasan diatas adalah sebagai berikut: (1) Tingkat literasi keuangan dalam penelitian ini secara keseluruhan adalah $71.15 \%$ berada pada kategori sedang. Nilai maksimal yang di dapatkan adalah 95\% dan nilai minimal yang didapatkan adalah 45\%. (2) Tingkat literasi keuangan siswa SMK N 1 Singaraja tergolong sedang karena $72,8 \%$ siswa memiliki rentang skor $60 \%-80 \%$ yang terdiri dari pengetahuan umum keuangan, pengetahuan simpanan, pengetahuan pinjaman, pengetahuan asuransi serta pengetahuan investasi. (3) Tingkat literasi keuangan siswa SMA N 4 Singaraja tergolong sedang karena $69 \%$ siswa memiliki rentang nilai $60 \%-80 \%$ yang terdiri dari pengetahuan umum keuangan, pengetahuan simpanan, pengetahuan pinjaman, pengetahuan asuransi serta pengetahuan investasi. (4) Perbandingan tingkat literasi keuangan siswa antara SMK N 1 Singaraja dan SMA N 4 Singaraja dilihat dari aspek statistik deskriptif, jumlah siswa dalam kategori tingkat literasi keuangan dan persentase jawaban benar pada indikator pertanyaan mendapatkan hasil SMK N 1 Singaraja lebih unggul dibandingkan dengan SMA N 4 Singaraja. Namun tidak terlalu signifikan karena tingkat literasi tidak berbeda terlalu jauh dan msih pada kategori yang sama.

Berdasarkan hasil penelitian dan analisis data yang dilakukan, maka saran yang dapat diberikan adalah sebagai berikut. (1) Bagi pemerintah dan sekolah untuk dapat meningkatkan literasi keuangan, Cara yang dapat ditempuh adalah pendidikan tentang literasi keuangan harus diperbanyak dan mengadakan buku-buku terkait dengan materi literasi keuanan di perpustakaan, selain itu juga dapat berkerjasama dengan OJK yang saat ini mempunyai program untuk meningkatkan literasi keuangan menuju well literate dan financially inclusive untuk mengadakan seminar atau menjadi tamu pengajar dalam kelas. dan (2) Peneliti selanjutnya diharapkan dapat memperluas objek penelitian untuk mendapatkan hasil penelitian yang lebih luas, memperbanyak informasi untuk mendapatkan hasil penelitian yang lebih mendalam lagi. 


\section{Daftar Rujukan}

Anshori, M \& Iswati, S. (2009). Metodologi Penelitian kuantitatif. Surabaya : Pusat Penerbitan Dan Percetakan Unair.

Arviana, G. (2019). “Ini Empat Akibat Jika Literasi Keuangan Rendah”. Tersedia pada Finansial.bisnis.com (diakses tanggal 09 September 2019).

Cahyani, D. (2017). “OJK: Literasi Keuangan Masuk Kurikulum SD SMP Tahun Depan”. Tersedia pada Bisnis.tempo.co (diakses 20 desember 2019)

Chen, H.\& Volpe, R. P. (1998)“ An Analysis of Personal Financial Literacy among College Students”. Financial Services Review, 7(2), 107.

Endra, F. (2017). Pedoman Metodologi Penelitian (Statistika Praktis). Sidoarjo: Zifatama Jawara.

Fahmar, S, K. (2017). “OJK Dorong Masyarakat Punya Sikap Keuangan”. Tersedia pada Sindonews.com (diakses pada 08 September 2019).

Hidajat, T. (2016). Literasi Keuangan. Jawa tengah: STIE Bank BPD.

Humaira, I. (2018). Pengaruh Pengetahuan Keuangan, Sikap Keuangan, Dan Kepribadian Terhadap Perilaku Manajemen Keuangan Pada Pelaku UMKM Sentra Kerajinan Batik Di Bantul. Jurnal Akuntansi.Universitas Negeri Yogyakarta. Vol. 7, No. 1.

Mabyakto, G. (2017). Analisis Tingkat Literasi Keuangan Mahasiswa. Jurnal Manajemen. Universitas Sanata Dharma. Vol 17, No.1

Setiawati, A. N. (2017). "Pengujian Dimensi Konstruk literasi keuangan Mahasiswa". Journal Unnes Volume 3 (Halaman 730).

Sugiyono. (2011). Metode Penelitian Kuantitatif, Kualitatif dan R\&D. Bandung: Alfabeta

Sugiyono. (2013). Metode Penelitian Bisnis. Bandung: Alfabeta. 